\title{
Direct radiative effects of dust aerosols emitted from the Tibetan Plateau on the East Asian summer monsoon - a regional climate model simulation
}

\author{
Hui Sun ${ }^{1}$, Xiaodong Liu ${ }^{1,2}$, and Zaitao Pan $^{3,4}$ \\ ${ }^{1}$ SKLLQG, Institute of Earth Environment, Chinese Academy of Sciences, Xi' an, 710061, China \\ ${ }^{2}$ CAS Center for Excellence in Tibetan Plateau Earth Sciences, Beijing, 100101, China \\ ${ }^{3}$ Department of Earth and Atmospheric Sciences, Saint Louis University, St. Louis, Missouri, MO 63108, USA \\ ${ }^{4}$ Key Laboratory of Meteorological Disaster, Ministry of Education, Nanjing University of Information Science and \\ Technology, Nanjing, Jiangsu, China
}

Correspondence to: H. Sun (sunhui@ieecas.cn)

Received: 21 January 2017 - Discussion started: 28 February 2017

Revised: 17 September 2017 - Accepted: 9 October 2017 - Published: 17 November 2017

\begin{abstract}
While dust aerosols emitted from major Asian sources such as Taklimakan and Gobi deserts have been shown to have strong effect on Asian monsoon and climate, the role of dust emitted from Tibetan Plateau (TP) itself, where aerosols can directly interact with the TP "heat pump" because of their physical proximity both in location and elevation, has not been examined. This study uses the dustcoupled RegCM4.1 regional climate model (RCM) to simulate the spatiotemporal distribution of dust aerosols originating within the TP and their radiative effects on the East Asian summer monsoon (EASM) during both heavy and light dust years. Two 20-year simulations with and without the dust emission from TP showed that direct radiative cooling in the mid-troposphere induced by the TP locally produced dust aerosols resulted in an overall anticyclonic circulation anomaly in the low troposphere centered over the TP region. The northeasterly anomaly in the EASM region reduces its strength considerably. The simulations found a significant negative correlation between the TP column dust load produced by local emissions and the corresponding anomaly in the EASM index $(r=-0.46)$. The locally generated TP dust can cause surface cooling far downstream in Bohai Gulf and the China-North Korea border area through stationary Rossby wave propagation. Although dust from within TP (mainly Qaidam Basin) is a relatively small portion of total Asian aerosols, its impacts on Asian monsoon and climate seems disproportionately large, likely owning to its higher elevation within TP itself.
\end{abstract}

\section{Introduction}

Dust is one of the most important components of atmospheric aerosols. The main source of atmospheric dust is wind erosion in arid and semi-arid regions; it is estimated that the global atmospheric dust emission may be as high as 200 $5000 \mathrm{Mt} \mathrm{yr}^{-1}$ (Goudie, 1983). Because of the large amount in the atmosphere, dust effects on the environment and the climate system have attracted much attention. The inhalation of dust aerosols can harm both human and animal health; it can also affect visibility and thus potentially increase the number of traffic accidents (Park and Kim, 2005). Dust aerosols also are important drivers of the global climate because of their direct radiative effects on the Earth-atmosphere radiation balance and temperature (Tegen and Lacis, 1996; Miller et al., 2004). They can alter the atmospheric hydrological cycle by acting as cloud condensation nuclei and thus can modulate both the regional and global precipitation (Rosenfeld et al., 2001). Satellite observations have shown that dust originating from the Taklimakan Desert can travel around the globe within 2 weeks and alter the interaction between the atmospheric $\mathrm{CO}_{2}$ and the global climate by providing nutrients to and interacting with the marine ecosystem (Uno et al., 2009).

East Asia is an important source region for dust (Zhang et al., 1996) and is home to more than half of the world's population. The lives of people in East Asia are deeply affected by the East Asian summer monsoon (EASM) and the 
relationship between dust aerosols and the EASM is of great interest to the scientific community. Simulations have shown that dust aerosols not only weaken the EASM (Sun et al., 2012; Guo and Yin, 2015), but can also reduce the atmospheric heat source over the Tibetan Plateau (TP) and delay the onset of the EASM (Sun and Liu, 2016). Aerosols, including dust aerosols, have been shown to affect the intensity of the EASM (Li et al., 2016) and variations in the EASM can modulate the spatiotemporal distribution of dust aerosols in East Asia. A recent modeling study by Lou et al. (2016) indicated that there was a negative correlation between the spring dust loading in eastern China and the East Asian monsoon.

Dust aerosols in East Asia are mainly derived from arid and semi-arid areas, including the Taklimakan and Gobi deserts. However, some studies have indicated that the TP itself may also be an important source region for dust (Zhang et al., 1996; Fang et al., 1999) and that the region is more conducive to the atmospheric transportation of dust due to its high altitude and can interact directly with the TP thermal pump (Wu et al., 2012). However, the source and spatiotemporal distribution of dust aerosols over the TP have not been established yet. At present, there are three viewpoints about the source of dust aerosols over the TP. First, an investigation by Fang et al. $(1995,1999)$ showed that there exists $2047.41 \times 10^{4}$ ha of desert within the TP, suggesting that the TP may be a potential source for dust. A numerical simulation by Chen et al. (2013) showed that dust aerosols were produced by local emissions over the TP in spring and winter. Second, satellite observations have shown that the aerosols over the TP are dominated by dust in spring and summer and that the dust aerosols were probably derived from the Taklimakan and Gurbantunggut deserts to the north of the TP (Huang et al., 2007; Jia et al., 2015). Third, some studies have indicated that the dust emitted from the south of the TP, such as from the Great Indian Desert, can also be transported over the Himalaya (Lau et al., 2006, 2010).

As a massive, elevated heat source, the TP can directly heat the upper troposphere. The heating anomaly over the TP has a great impact on the EASM (Yanai et al, 2006; Duan et al., 2012). Studies have shown that dust aerosols over the TP can alter the local atmospheric radiation balance, affecting both the heat source over the TP and the Asian monsoon (Lau et al., 2006, 2010; Chen et al., 2013; Sun et al., 2016). However, most previous simulation studies have focused on dust aerosols originating from the Taklimakan and Gobi deserts (Zhao et al., 2006; Wang et al., 2008; Huang et al., 2009; Sun et al., 2012), and there have been few investigations of the impact of dust aerosols emitted by the TP on the East Asian climate. The work reported here used the RegCM4.1 model to simulate climatic effects of distribution of dust aerosols surrounding the TP by performing numerical experiments with and without the emission of dust over the TP.

\section{Numerical model and experiment design}

\subsection{RegCM4.1 model}

We used the RegCM4.1 model (Regional Climate Model version 4.1), which is developed and supported by the National Center for Atmospheric Research (NCAR) and the International Center for Theoretical Physics. The model has been widely used for more than 20 years in studies of regional climatic and environmental change, especially in the simulation of the effect of aerosols on climate (Qian et al., 2003; Solmon et al., 2008; Zhang et al., 2009; Zanis et al., 2012; Ji et al., 2011, 2015; Das et al., 2015a, 2016; Mbienda et al., 2017).

The dynamic framework of RegCM4.1 core is based on the hydrostatic core of the mesoscale model MM5 (Grell et al., 1994). The radiation scheme in RegCM4.1 is the CCM3 radiation transfer process (Kiehl et al., 1996). RegCM4.1 has two land surface process schemes: (1) the biosphere atmosphere transfer scheme (BATS1e; Dickinson et al., 1993) and (2) the Common Land Surface process module (CLM3.5; Oleson et al., 2008). The dust cycle can only be diagnosed when BATS1e is used. The planetary boundary layer parameterization in RegCM4.1 follows the scheme of Holtslag et al. (1990) and there are three cumulus convection parameterization schemes, including Grell (Grell et al., 1993), Kuo (Anthes, 1977) and MIT-Emanuel (Emanuel, 1991). The dust module coupled in RegCM4.1 is based on the dust emission model (DPM) of Marticorena et al. (1995) and Alfaro and Gomes (2001). It considers dust emission, dry/wet deposition and the diagnosis of the optical and radiation characteristics of dust (including long- and shortwave radiation; Zakey et al., 2006; Zhang et al., 2009).

The dust-coupled module has been described in detail in previous articles (Zakey et al., 2006; Zhang et al., 2009), so only a brief introduction is given here. There are four steps in dust parameterization. First, each model grid cell is classified as either desert or non-desert according to its soil properties (such as texture, soil type, particle size and composition) based on the United States Department of Agriculture textural classification. Second, dust emission is assumed to be a function of friction velocity $\left(u^{*}\right)$; dust aerosols are lifted off the ground once $u^{*}$ exceeds a threshold value $\left(u_{t}^{*}\left(D_{\mathrm{p}}\right)\right)$.

$u_{t}^{*}\left(D_{\mathrm{p}}\right)=u_{\mathrm{ts}}^{*}\left(D_{\mathrm{p}}\right) \cdot f_{\mathrm{eff}} \cdot f_{\mathrm{w}}$,

where $u_{\mathrm{ts}}^{*}\left(D_{\mathrm{p}}\right)$ depends on soil particle size $\left(D_{\mathrm{p}}\right)$, and $f_{\text {eff }}$ and $f_{\mathrm{w}}$ are the correction terms for non-erodible surface roughness elements (Marticorena and Bergametti, 1995) and soil moisture content (Fécan et al., 1999), respectively. 
Third, the horizontal mass flux is treated as a function of the frictional velocity and is given by

$$
\begin{aligned}
& \mathrm{d} H_{F}\left(D_{\mathrm{p}}\right)= \\
& E \cdot \frac{\rho_{a}}{g} \cdot u^{* 3} \cdot\left(1+R\left(D_{\mathrm{p}}\right)\right) \cdot\left(1-R^{2}\left(D_{\mathrm{p}}\right)\right) \cdot \mathrm{d} S_{\text {rel }}\left(D_{\mathrm{p}}\right),
\end{aligned}
$$

where $E, \rho_{a}$ and $g$ are the ratio of the erodible to total surface areas, the surface air density and the gravitational acceleration, respectively. $R\left(D_{\mathrm{p}}\right)$ is the ratio of the threshold frictional velocity in Eq. (1) to the frictional velocity $u^{*}$ calculated within each grid cell from model prognostic surface wind and surface roughness height. $d S_{\text {rel }}\left(D_{\mathrm{p}}\right)$ is the relative surface area of a soil aggregate of diameter $D_{\mathrm{p}}$ to the total surface area of soil aggregates. The vertical flux corresponding to each emission mode is calculated by

$F_{\text {dust }, i}\left(D_{\mathrm{p}}\right)=\left(\frac{\pi}{6}\right) \cdot \rho_{\mathrm{p}} \cdot D_{i}^{3} \cdot N_{i}$,

where $\rho_{\mathrm{p}}$ is the aggregate density $\left(2.65 \mathrm{~g} \mathrm{~cm}^{-3}\right), D_{i}$ is the median diameter and $N_{i}$ is a function of the kinetic energy flux.

The dust particles are divided into four size bins (or modes): fine $(0.01-1.0 \mu \mathrm{m})$, accumulation $(1.0-2.5 \mu \mathrm{m})$, coarse $(2.5-5 \mu \mathrm{m})$ and giant $(5.0-20.0 \mu \mathrm{m})$. The dust transport, deposition and removal processes are given by Qian et al. (2001) and Qian and Giorgi (1999):

$$
\frac{\partial \chi^{i}}{\partial t}=-\bar{V} \cdot \nabla \chi^{i}+F_{\mathrm{H}}^{i}+F_{\mathrm{V}}^{i}+F_{\mathrm{C}}^{i}+S^{i}-R_{\mathrm{Wls}}^{i}-R_{\mathrm{Wc}}^{i}-D_{\mathrm{d}}^{i} \text {, }
$$

where $\chi$ is the dust mixing ratio, $\bar{V}$ is vector wind and $-\bar{V} \cdot \nabla \chi^{i}$ is the advection, $F_{\mathrm{H}}^{i}$ is the horizontal turbulent diffusion, $F_{\mathrm{V}}^{i}$ is the vertical turbulent diffusion and $F_{\mathrm{C}}^{i}$ is the convective transport. $R_{\mathrm{Wls}}^{i}$ and $R_{\mathrm{Wc}}^{i}$ are the wet removal terms, represented by large-scale and convective precipitation. $D_{\mathrm{d}}^{i}$ is the dry deposition, represented by assuming fixed depositional velocities over both land and water.

The dust SW radiation is calculated using an asymmetry factor, single-scattering albedo (SSA) and mass extinction coefficient based on Mie theory. Radiative flux calculation use the $\delta$-Eddington approximate, and the optical spectrum is within $0.2-4.5 \mu \mathrm{m}$ and is divided into 18 wavelength bands. One is in the visible band. Seven are in the ultraviolet band between 0.2 and $0.35 \mu \mathrm{m}$, and the rest are in the infrared band. Refractive index of dust for the SW window is from the Optical Properties of Aerosols and Clouds (OPAC) database (Hess et al., 1998). The dust SSA of the four bins is considered to be $0.95(0.01-1.0 \mu \mathrm{m}), 0.89(1.0-2.5 \mu \mathrm{m}), 0.80$ $(2.5-5.0 \mu \mathrm{m})$ and $0.7(5.0-20.0 \mu \mathrm{m})$, respectively. The corresponding extinction efficiencies are $2.45,0.85,0.38$ and 0.17 , and asymmetry parameters are $0.64,0.76,0.81$ and 0.87 , respectively. In the LW domain, dust effects on emissivity (and hence absorptivity) use the parameterization of Kiehl et al. (1996).

$\varepsilon_{\mathrm{LW}}(z)=1-\ell^{-D \cdot k_{\mathrm{lwabs}} \cdot b(z)}$, where $D=1.66$ is the diffusivity factor, $b(z)$ is the dust burden $\left(\mathrm{g} \mathrm{m}^{-2}\right)$ of a given layer and $k_{\text {lwabs }}\left(\mathrm{m}^{2} \mathrm{~g}^{-1}\right)$ is the mass absorption coefficient calculated based on the Mie theory for each size bin of the relevant LW spectral windows using the LW refractive indices consistent with Wang et al. (2006).

\subsection{Experimental design and observational data}

Two numerical experiments were designed; both integrate for 20 years (excluding first 2 years of spin-up) using the dustcoupled RegCM4.1. The first experiment was a control experiment $(\mathrm{CON})$ that used the default land use types from the Global Land Cover Characterization data set (Loveland et al., 2000), meaning that dust-emitting sources both within and outside the TP are present. The second experiment was a sensitivity experiment (SEN), where we turned off the dust emission in the northern and northeastern TP (the deserts inside the black outline of the TP contour in Fig. 1b). To eliminate the dust emission in the TP, we set $u_{t}^{*}\left(D_{\mathrm{p}}\right)$ in Eq. (2) and $F_{\text {dust, } i}\left(D_{\mathrm{p}}\right)$ in Eq. (3) to zero over the TP. All the other conditions in the sensitivity experiment were the same as in the control experiment. In order to isolate the effect of dust aerosols, only dust aerosols are included in our simulations, without considering other aerosols (such as anthropogenic or marine aerosols).

The initial and boundary conditions were taken from the NCAR/NCEP re-analysis data set (Kalnay et al., 1996). The sea surface temperature used the National Oceanic and Atmospheric Administration sea surface temperature data set (Reynolds et al., 2002). The topography of the TP is very complex, necessitating high spatial resolution $(<60 \mathrm{~km})$ to resolve localized precipitation (Gao et al., 2006). The horizontal resolution in $\mathrm{RegCM} 4.1$ runs was therefore set to $40 \mathrm{~km}$. The simulation domain is shown in Fig. 1a and the model domain center was at $32^{\circ} \mathrm{N}, 105^{\circ} \mathrm{E}$ with 240 grid cells in the west-east direction and 160 grid cells in the north-south direction. The model was run in the standard configuration of 18 vertical $\sigma$ layers with the model top at $10 \mathrm{hPa}$. The integration duration for both experiments was from 1 January 1988 to 31 December 2009. The first 2 years were treated as the model spin-up time, and only the results from the last 20 years were analyzed.

Five main types of observations were used to evaluate the simulated results of CON:

1. The monthly mean surface air temperature and precipitation, with a high resolution of $0.5^{\circ} \times 0.5^{\circ}$, provided by the Climate Research Unit (CRU) of the University of East Anglia (Mitchell and Jones, 2005), which was used to evaluate the simulated surface temperature and precipitation in CON.

2. The NCEP-DOE re-analysis wind field $\left(2.5^{\circ} \times 2.5^{\circ}\right)$ at $850 \mathrm{hPa}$, which was used to compare the simulated atmospheric circulation. 

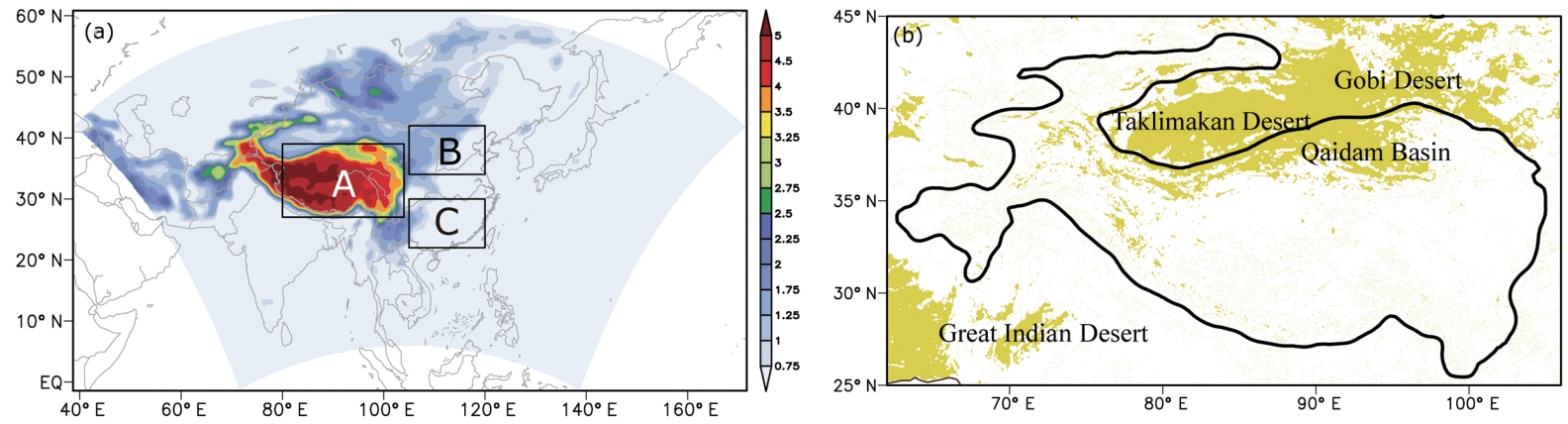

Figure 1. (a) Model domain and topography (units: km) and (b) dust source regions (yellow area) over the Tibetan Plateau and surrounding areas. Rectangles in (a) indicate Tibetan Plateau $\left(\mathrm{A} ; 27-39^{\circ} \mathrm{N}, 80-105^{\circ} \mathrm{E}\right)$, north EASM region $\left(\mathrm{B} ; 34-42^{\circ} \mathrm{N}, 105-120^{\circ} \mathrm{E}\right)$ and south EASM region $\left(\mathrm{C} ; 22-30^{\circ} \mathrm{E}, 105-120^{\circ} \mathrm{N}\right)$.

3. Level-3 monthly mean aerosol optical depth (AOD) data from 2000 to 2009 obtained from the Multiangle Imaging Spectroradiometer (MISR) onboard NASA's Earth Observation System Terra satellite (http://www-misr. jpl.nasa.gov/). Since MODIS AOD has a large portion of missing data in northwest China, MISR was used to evaluate the simulated dust AOD in CON. The effectiveness of the MISR data was investigated by Martonchik et al. $(1998,2004)$ and Bibi et al. (2015).

4. Level-3 monthly mean pure dust AOD data under cloudfree scenes $\left(2^{\circ} \times 5^{\circ}\right)$ from 2007 to 2009 obtained from Cloud-Aerosol Lidar and Infrared Pathfinder Satellite Observations (CALIPSO; Winker et al., 2013), which was also used to evaluated the simulated dust AOD in CON. The most recent version of the L3 product included averaging of individual types of aerosols (Liu et al., 2008; Amiridis et al., 2013; Marinou et al., 2017).

5. The AOD observed in situ by the Aerosol Robotic Network (AERONET), which was used to evaluate the simulated dust seasonal and interannual variation in $\mathrm{CON}$.

\section{Results of simulations}

In this section we will first evaluate the CON simulation using the observed data described in the previous section. Then the results from CON and SEN experiments will be compared to determine the roles of dust aerosols generated from the TP play in the thermodynamic fields and circulations including the EASM.

\subsection{Validation}

\subsubsection{Basic model climatology}

The simulated climatology can influence the distribution of dust aerosols and their climatic effects, so CON was used to analyze the surface temperature, precipitation and atmospheric circulation at $850 \mathrm{hPa}$. The $\mathrm{CON}$-simulated and
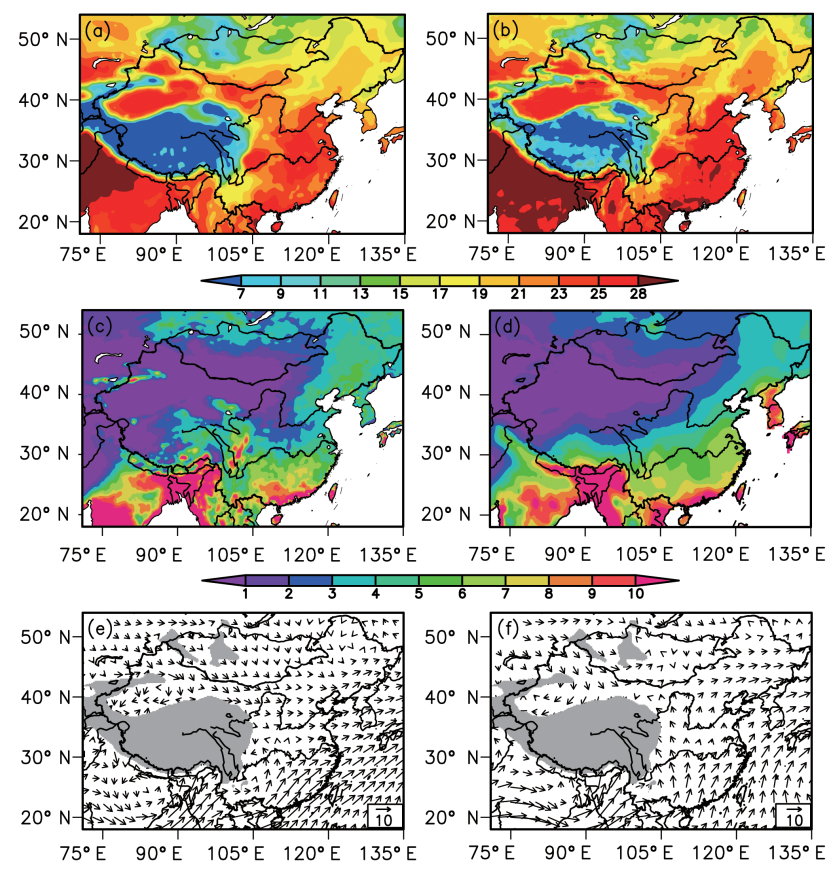

Figure 2. Spatial distribution of (a, b) summer surface air temperature $\left({ }^{\circ} \mathrm{C}\right)$ and $(\mathbf{c}, \mathbf{d})$ summer precipitation $\left(\mathrm{mm} \mathrm{day}^{-1}\right)$ simulated in the control experiment (a, c, e) and the CRU observations (b, d, f) for 1990-2009. The bottom two panels are wind vectors at $850 \mathrm{hPa}$ simulated in (e) the control experiment and (f) the NCEP-DOE reanalysis during the summer monsoon season (June-August) averaged for 1990-2009.

CRU-observed 20-year average summer surface temperatures in East Asia are presented, respectively, in Fig. 2a and $b$. The CRU-observed temperature is $>25^{\circ} \mathrm{C}$ in southern China, NW China and northern India, and it is $<7^{\circ} \mathrm{C}$ over the TP. The observed north-south gradient and location of the maximum and minimum centers were captured well. The model captured the major distribution patterns of precipitation, including the reasonable SE-NW gradient and the maximum centers in southern China, the Himalaya and Indian 

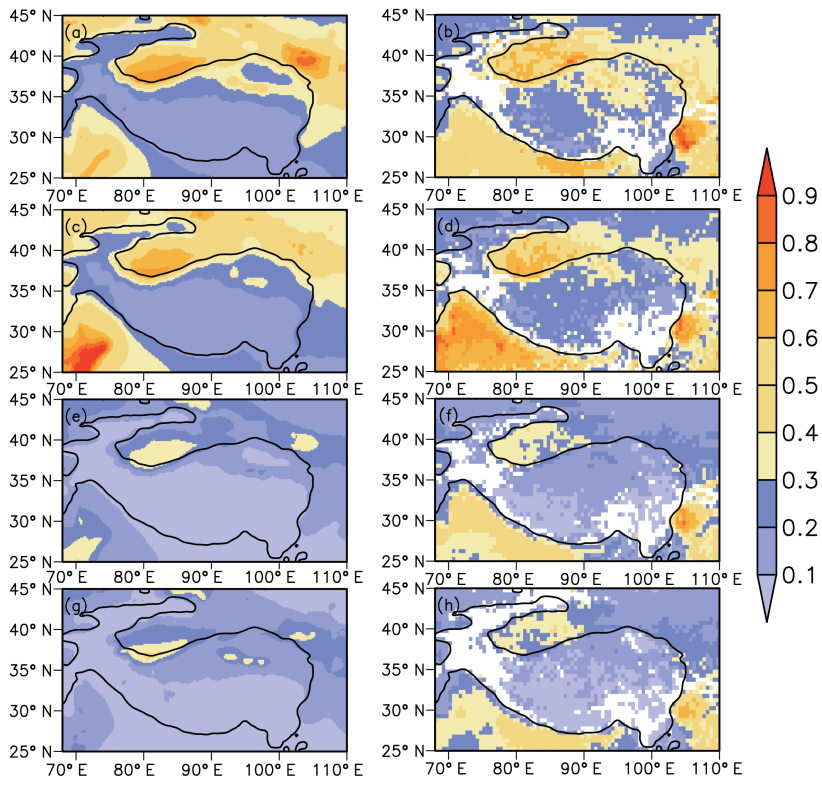

Figure 3. Spatial distribution of the dust AOD simulated by the control experiment (a, $\mathbf{c}, \mathbf{e}, \mathbf{g})$ and the total AOD observed by MISR at $550 \mathrm{~nm}(\mathbf{b}, \mathbf{d}, \mathbf{f}, \mathbf{h})$ averaged in $(\mathbf{a}, \mathbf{b})$ spring, $(\mathbf{c}, \mathbf{d})$ summer, $(\mathbf{e}, \mathbf{f})$ autumn and $(\mathbf{g}, \mathbf{h})$ winter during the time period 2000-2009.

Peninsula, with a $2-4 \mathrm{~mm} \mathrm{day}^{-1}$ negative bias in the Korean Peninsula and southern Japan and a $2-4 \mathrm{~mm} \mathrm{day}^{-1}$ positive bias in the Tianshan (Fig. 2c, d). These simulated deviations are likely related to the cumulus convective scheme in the model (Zhang et al., 2008; Wang and Yu, 2011). RegCM4.1 captured the major characteristics of the circulations in East Asia, where southwesterlies dominate to the south side of the $\mathrm{TP}$, and the location of the Indian Low is consistent with the NCEP-DOE observations (Fig. 2e, f).

\subsubsection{Simulated and MISR-observed dust AOD comparison}

Satellite and in situ observations include all types of aerosols, such as black aerosols, $\mathrm{SO}_{2}$ and organic carbon; observed data for dust AOD alone are scarce. Therefore we used the MISR AOD data, as in most previous studies (e.g., Zakey et al., 2006; Zhang et al., 2009), to evaluate the spatiotemporal distribution of the dust AOD simulated by the model. Both the simulation and observations showed that the dust AOD over the TP and its surrounding areas was higher in spring and summer (Fig. 3a and c) and lower in autumn and winter (Fig. 3e and g). There were three maximum centers $(>0.6)$ of dust AOD in spring and summer, located in the Taklimakan, Gobi and Great Indian deserts, respectively. The dust AOD over the Qaidam Basin in the NE of the TP was also $>0.5$ and the dust AOD over the northern TP, adjacent to the southern Taklimakan Desert, was between 0.3 and 0.5. The simulated dust AOD in these regions was reduced in autumn and winter (Fig. 3e and g). The MISR-observed AOD was

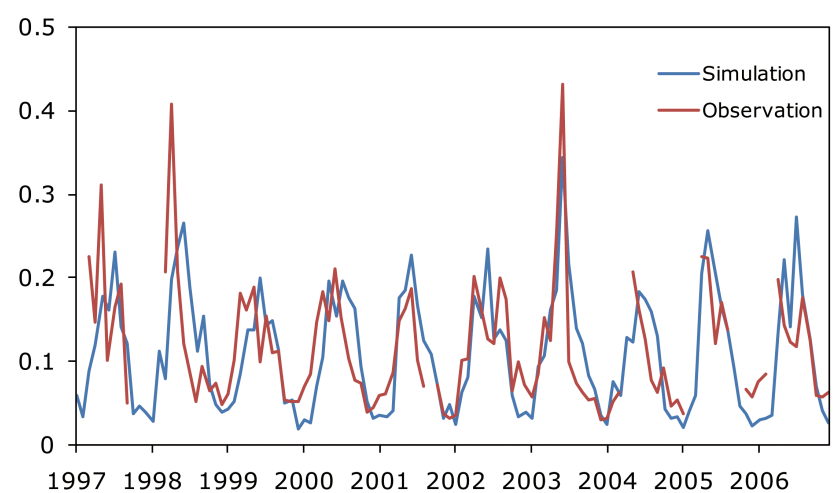

Figure 4. Comparison between the simulated variation of the monthly mean dust AOD in the control experiment and the AERONET-observed variation of the monthly mean aerosol AOD $(500 \mathrm{~nm})$ at Dalanzadgad from 1997 to $2006(r=0.66)$.

largely consistent with the model results for the Taklimakan and Gobi deserts and the Qaidam Basin, but was relatively low in the Great Indian Desert in summer. The large value of the MISR AOD in the Sichuan Basin to the east of the TP was due to industrial emissions, which were not incorporated into our model simulation.

\subsubsection{Simulated and AERONET-observed dust AOD comparison}

Figure 4 compares the in situ observed monthly mean AOD from AERONET and that simulated by RegCM4.1 at Dalanzadgad $\left(43.6^{\circ} \mathrm{N}, 104.4^{\circ} \mathrm{E}\right)$. This is the only available AERONET site in the vicinity of the dust sources with continuous records for $>10$ years. The model captured the seasonal and interannual variations of AOD well, including the year with extremely high levels of dust. Observations over the TP are scarce and we could only find a site with continuous aerosol records from AERONET at Nam Co $\left(30.77^{\circ} \mathrm{N}\right.$, $\left.90.96^{\circ} \mathrm{E}\right)$. The seasonal variation of AOD at this site is well captured. Both the simulation and the observations showed that the dust AOD increases in spring at Nam Co (Fig. 5).

\subsubsection{Simulated and CALIPSO-observed dust AOD comparison}

While MISR and AERONET data contain all types of aerosols including those anthropogenic ones, the CALIPSO observation is solely devoted to dust aerosols. Figure 6 shows that the simulated seasonal variation, center positions and magnitude of dust AOD are very consistent with those observed by CALIPSO. Both simulations and observations not only showed that dust AOD increased in spring and summer and decreased in autumn and winter, but they also captured three maximum centers of dust AOD in Taklimakan and Great Indian deserts and Qaidam Basin located in the north- 

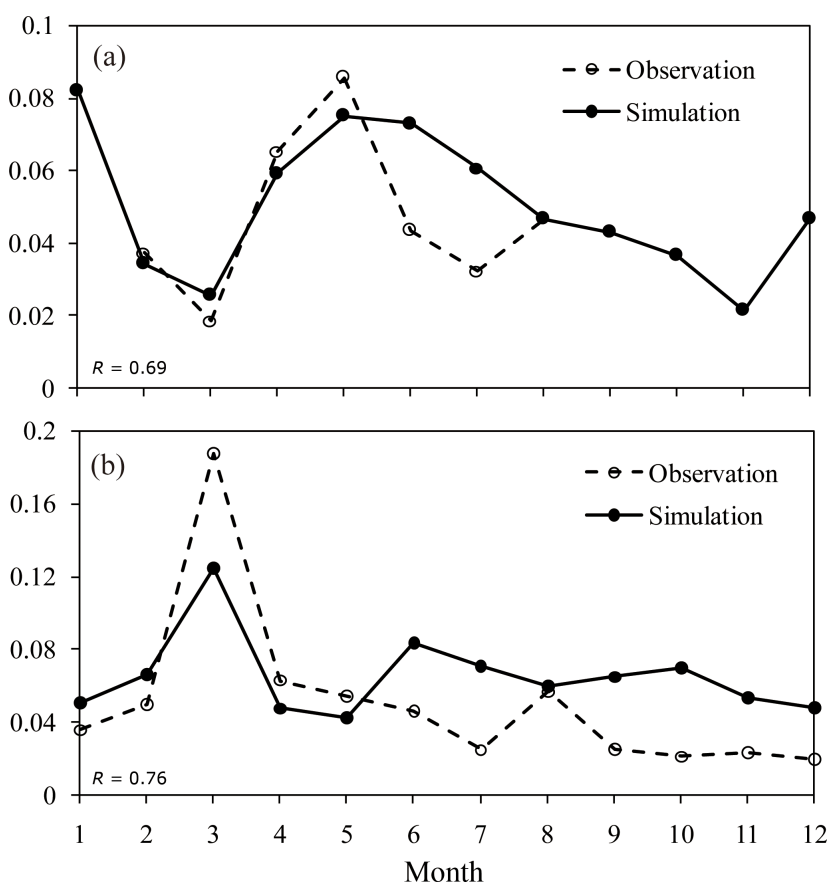

Figure 5. Comparison between the AERONET-observed monthly mean aerosol AOD $(500 \mathrm{~nm})$ at Nam Co and simulated by the control experiment at the grid near Nam Co in (a) 2007 and (b) 2009.

ern TP in spring. The simulated center values were still high in summer.

\subsection{Relationship between the EASM and dust loading over the TP}

To study the relationship between dust aerosols and the EASM, we used the average summer meridional wind at $850 \mathrm{hPa}$ over eastern China $\left(20-45^{\circ} \mathrm{N}, 105-122.5^{\circ} \mathrm{E}\right)$ as an EASM index, following Xie et al. (2016). This index measures the intensity of the southerly wind to the east of the TP in the lower troposphere over East Asia. It has been widely used to examine both modern and paleo-changes in the East Asian monsoon (Wang et al., 2008; Jiang and Lang, 2010). We found that the simulated difference in the EASM index (CON-SEN) and the difference in the model-simulated column dust load averaged over the TP are highly anticorrelated with a correlation coefficient $r=-0.46$ (Fig. 7). The dust aerosol increases and decreases over the TP as the index weakens and enhances, respectively. Lou et al. (2016) also demonstrated a clear negative correlation between the EASM and the dust concentration over eastern China in spring. Based on the variation in the column dust load shown in Fig. 7, we chose 1994 and 2009 as heavy dust years and 2003 and 2007 as light dust years and then contrasted the dust distribution over the TP and its effects on the summer climate in the heavy/light dust years.
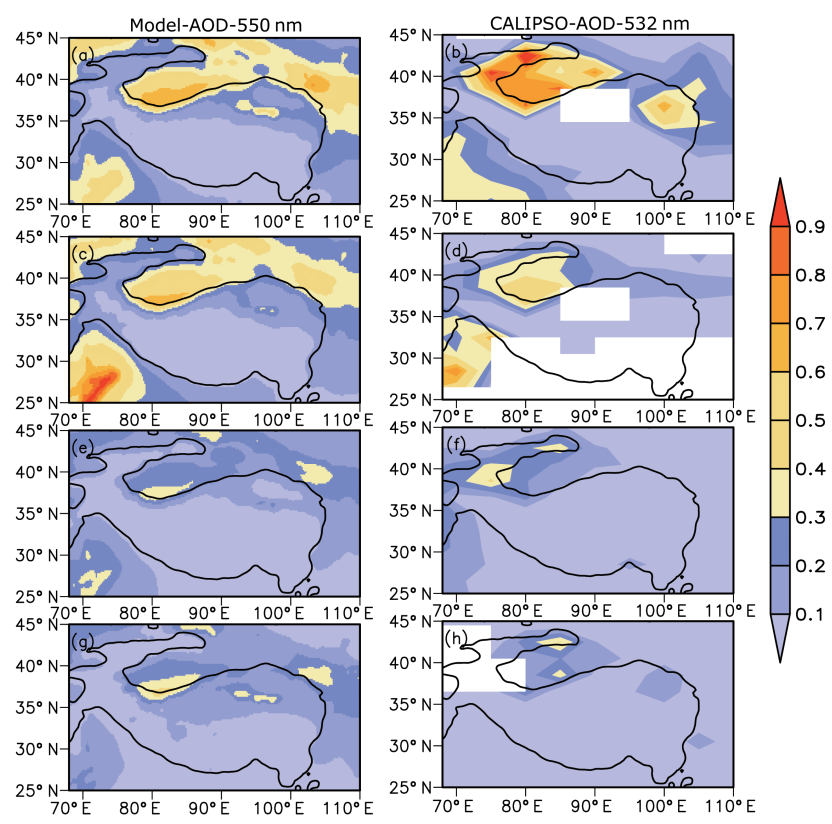

Figure 6. Spatial distribution of the dust AOD simulated by the control experiment (a, c, e, g) and the corresponding observed by CALIPSO (b, d, f, h) averaged in (a, b) spring, (c, d) summer, (e, f) autumn and (g, h) winter during the time period 2007-2009.

\subsection{Dust aerosol distribution in heavy/light dust years}

In the heavy dust years, the difference in the column dust load over the TP was greater than that in the light dust years, as expected. Two centers of maximum column dust load existed over the TP in the heavy dust years (Fig. 8a). One was located in the Qaidam Basin and the other was in the NW of the TP. The maximum values at both centers were $>70 \mathrm{mg} \mathrm{m}^{-2}$. However, the difference in the column dust load over the NW of the TP in the light dust years was much lower than in the heavy dust years and the average value was $<25 \mathrm{mg} \mathrm{m}^{-2}$. From the vertical profiles of the dust load (Fig. $8 \mathrm{c}$ and d), we can see that the dust mixing ratio was higher in heavy dust years in the western TP with an average value $>5 \mu \mathrm{gg}^{-1}$. The mixing ratio was lower in the western TP in the light dust years.

\subsection{East Asian climate anomalies in heavy/light dust years induced by dust aerosols}

\subsubsection{Temperature anomaly}

Both the atmospheric heating rate and the atmospheric temperature over the TP decreased in heavy/light dust years (Fig. 9). During the heavy dust years, the dust aerosol resulted in cooling anomaly centers in the lower troposphere $(600-400 \mathrm{hPa})$ over TP core, with a cooling of $>0.5 \mathrm{~K} \mathrm{day}^{-1}$ due to the large dust load. These cooling anomalies resulted in a low temperature center at $500 \mathrm{hPa}$ over the TP, with its 


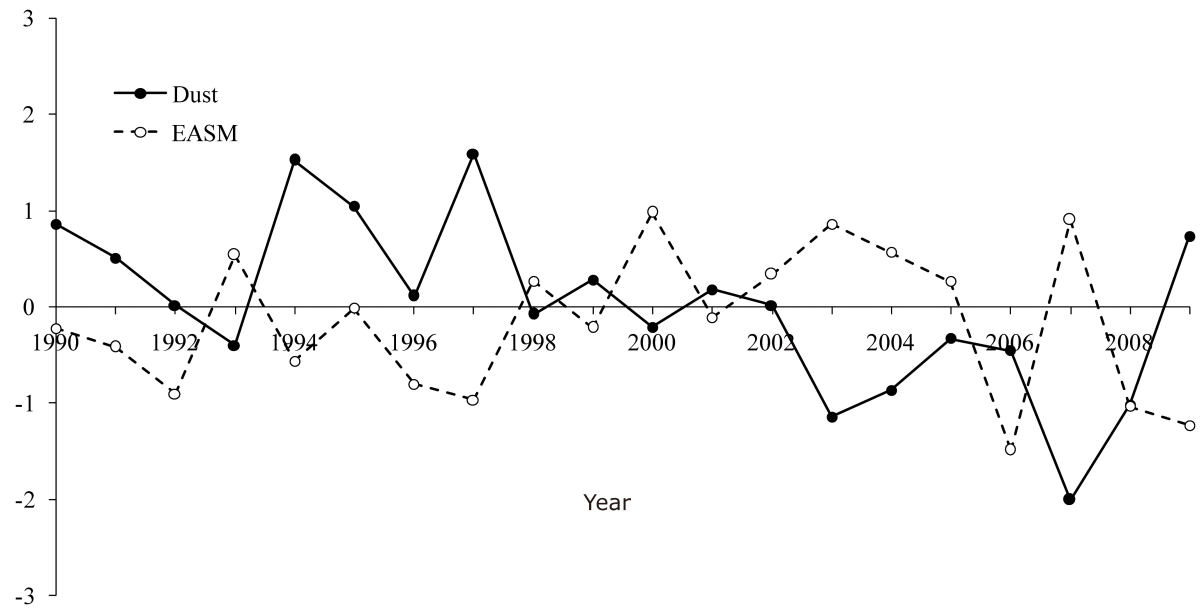

Figure 7. Difference of CON minus SEN in the normalized regional mean dust column load averaged over the Tibetan Plateau $\left(27-39^{\circ} \mathrm{N}\right.$, $\left.80-105^{\circ} \mathrm{E}\right)$ and in the EASM index for summer during the period 1990-2009 $(r=-0.46)$.
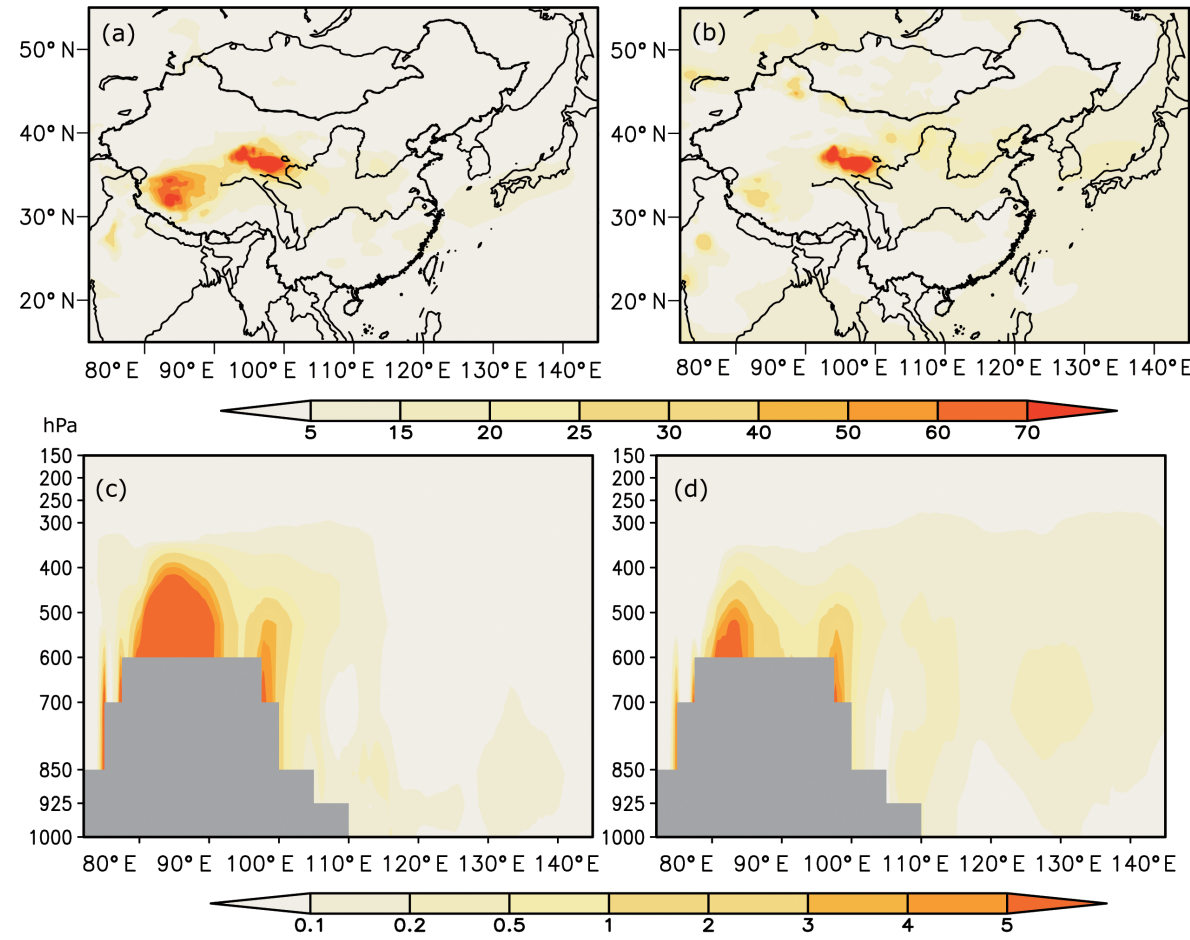

Figure 8. (a, b) Simulated differences (CON minus SEN) in the horizontal distribution of the column dust load (mg $\left.\mathrm{m}^{-2}\right)$ and $(\mathbf{c}, \mathbf{d})$ the longitude-height cross section (averaged over $32-36^{\circ} \mathrm{N}$ ) of the dust mixing ratio $\left(\mu \mathrm{g} \mathrm{kg}^{-1}\right)$ for summer in heavy (a, c) and light dust years $(\mathbf{b}, \mathbf{d})$.

average value reduced by $>0.8^{\circ} \mathrm{C}$. The dust aerosol load over the TP in the light dust years was much less than in the heavy dust years (Fig. 8a and c), so the cooling effect in the light dust years was weaker than in the heavy dust years.

The surface temperature over the TP decreased in both the heavy and light dust years (Fig. 10). In the heavy dust years, the surface temperature decreased by $0.6^{\circ} \mathrm{C}$ over the TP and consequently the sea-land thermal contrast was reduced. It is worth noting that the effects of TP aerosols on surface temperature were not limited to local or surrounding regions. In fact, the largest impact was in NE China, more than $2000 \mathrm{~km}$ away (Fig. 10a). The remote cooling is likely contributable to a cold air advection stemming from the upstream TP aerosols to be discussed in the next subsection (Fig. 11). Similar phenomena were reported earlier in Europe for anthropogenic 

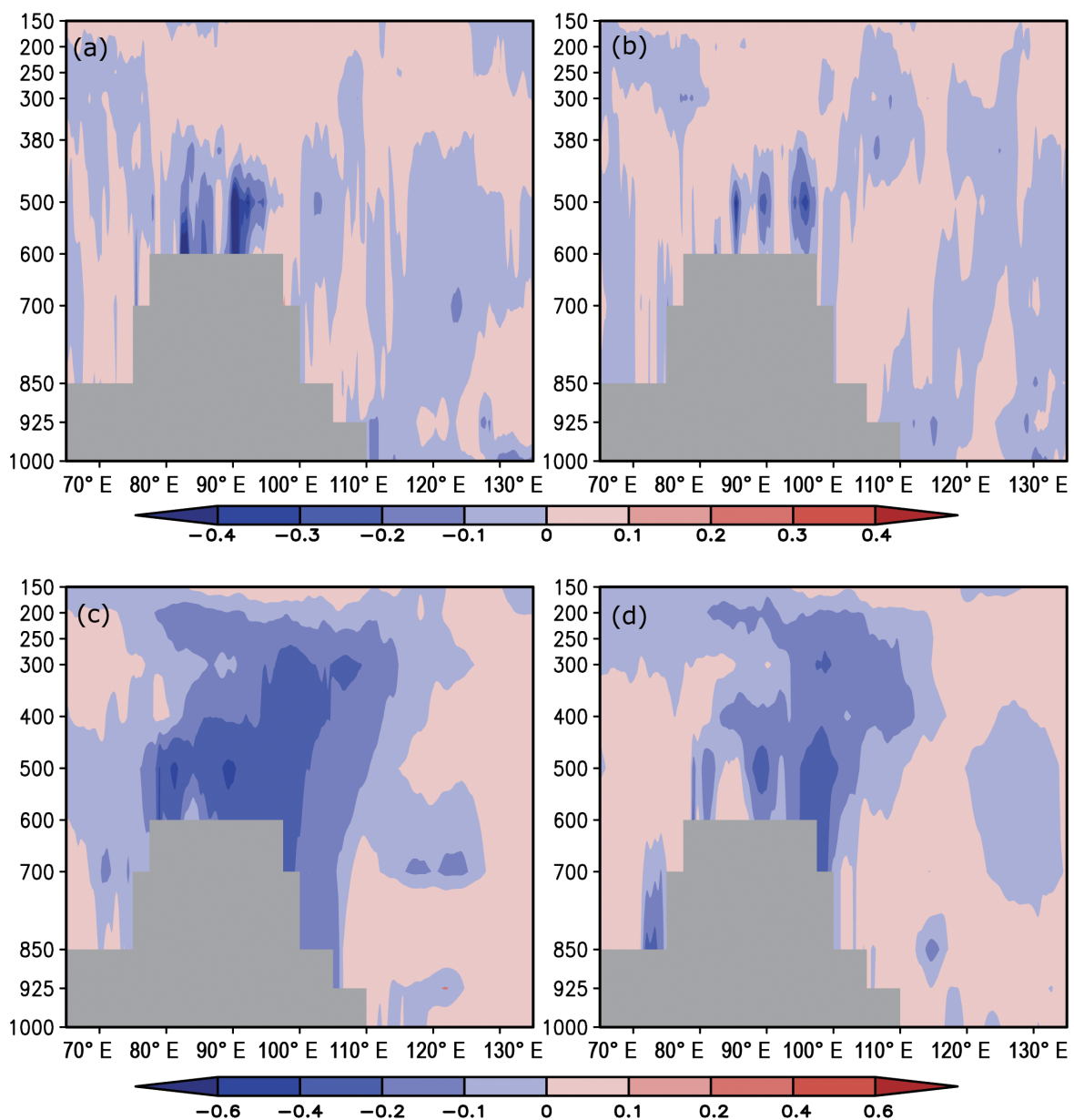

Figure 9. Longitudinal cross section of the differences between CON and SEN averaged over $32-36^{\circ} \mathrm{N}$ in summer. (a, b) Net radiative cooling rate (shortwave heating rate plus the longwave cooling rate, ${ }^{\circ} \mathrm{C}$ day ${ }^{-1}$ ) in heavy and light dust years, respectively. Panels (c) and (d) are similar to (a) and (b) but for atmospheric temperature $\left({ }^{\circ} \mathrm{C}\right)$.

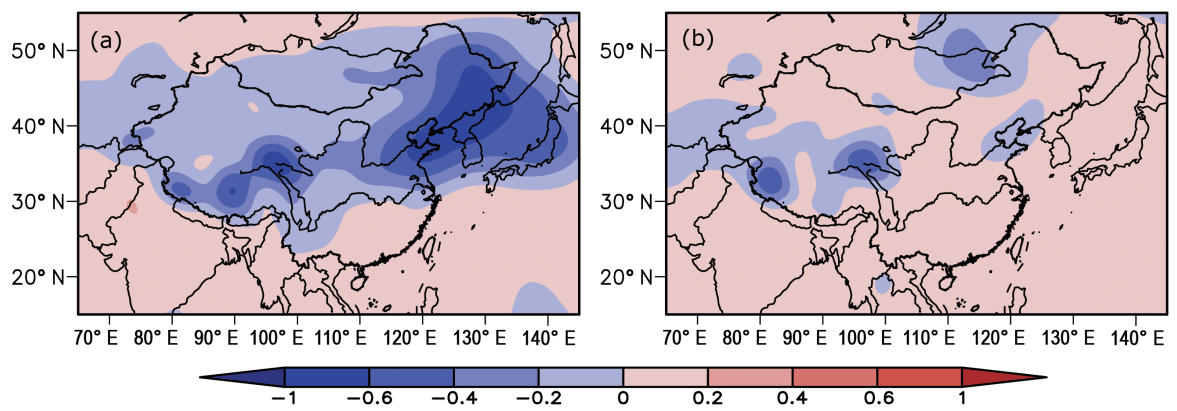

Figure 10. Simulated difference in summer surface air temperature between CON and SEN in (a) heavy and (b) light dust years.

aerosols (Zanis, 2009; Zanis et al., 2012) and in South Asia for natural aerosols (Das et al., 2015a).

\subsubsection{Circulation}

The overall effects of TP aerosols cool the troposphere surrounding the TP (Fig. 10a), and thus the land-sea thermal contrast was reduced by the dust aerosols over the TP. The atmospheric circulation anomaly induced by the dust aerosols emitted over the TP in heavy dust years shows an overall gigantic anticyclonic circulation centered over the TP with a positive anomaly $(>10 \mathrm{~m}$ ) at geopotential height (Fig. 11a). The northeasterlies that run against the southwesterly mon- 


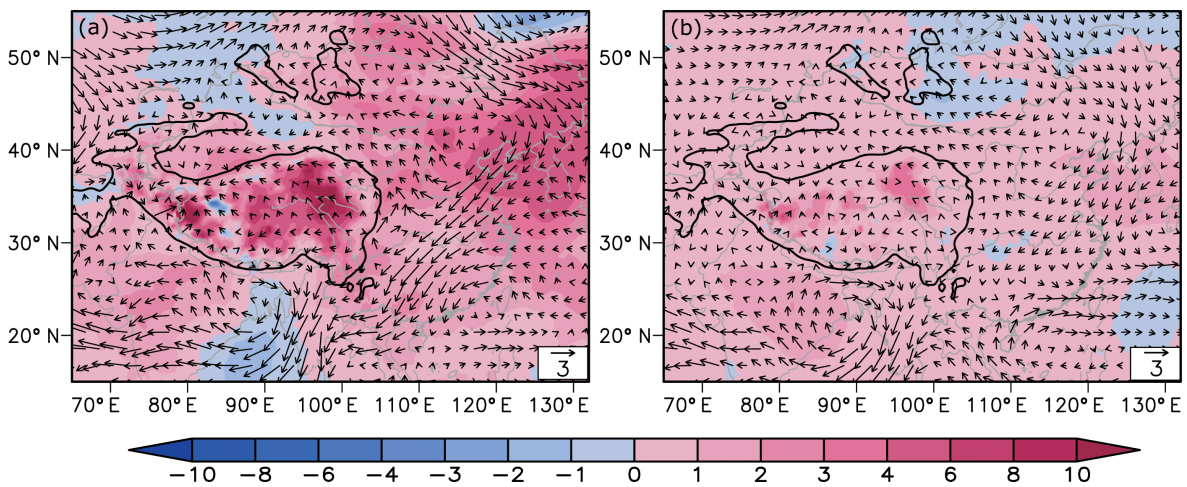

Figure 11. Simulated difference in atmospheric circulation at $850 \mathrm{hPa}$ (vector, $\mathrm{m} \mathrm{s}^{-1}$ ) and geopotential height at $600 \mathrm{hPa}(\mathrm{shaded}, \mathrm{m})$ in summer between CON and SEN in (a) heavy and (b) light dust years.

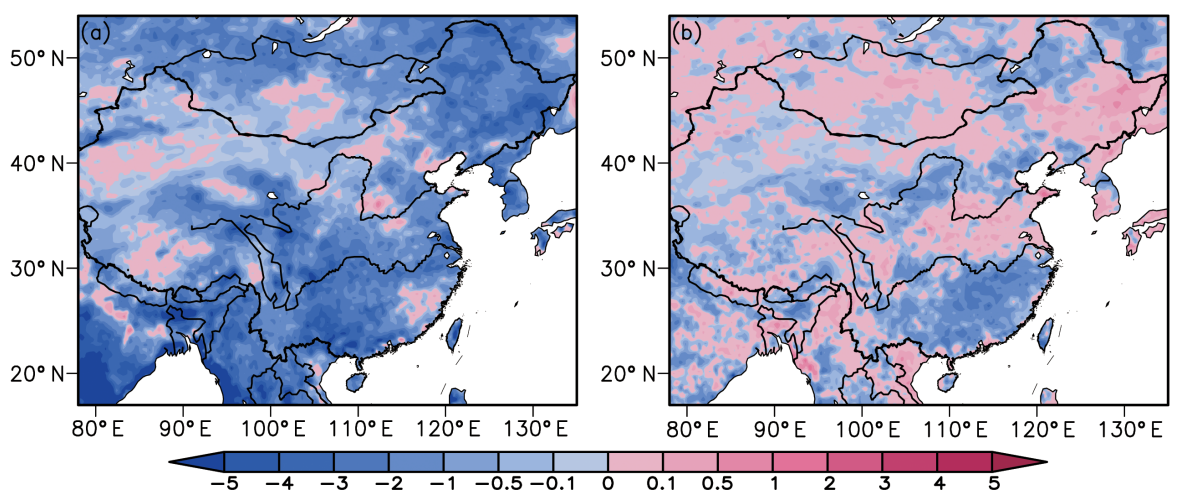

Figure 12. Simulated difference in summer precipitation between CON and SEN in (a) heavy and (b) light dust years.

soon are especially strong over the EASM region, which indicates that the EASM was weakened greatly. The anomaly still existed in the light dust years, but its intensity was much weaker than in the heavy dust years (Fig. 11b).

\subsubsection{Precipitation}

Figure 12 shows the simulated change in summer precipitation in East Asia induced by dust emitted over the TP in heavy and light dust years. The precipitation decreased in both the southern and the northern monsoon regions in summer in the heavy dust years as a result of weakening of the EASM (Fig. 11), and the reduction in the southern monsoon region is greater than that in the northern monsoon region. The dust aerosols also reduced precipitation in the two monsoon regions in the light dust years. This simulated suppressive effects of the dust aerosols were consistent with previously reported modeling results (Sun et al., 2012; Guo et al., 2015). In addition, precipitation in the heavy dust years reduced more than that in the light dust years in the TP, which may be due to the enhancement of descending motion induced by the strong cooling effects of dust aerosol over the TP.

\section{Discussion}

Previous research has shown that dust emitted from Asian deserts can weaken the EASM (Sun et al., 2012; Guo et al., 2015; Li et al., 2016), although the details of weakening mechanisms are still unclear. It has been suggested by some authors that the weakening of the EASM is a result of the reduction in the thermal contrast between the land and the sea induced by dust aerosols (Guo and Yin, 2015; Li et al., 2016). However, the modeling result of Sun et al. (2012) showed that the EASM is reduced by the large-scale atmospheric circulation disturbances (cycloneanticyclone-cyclone Rossby wave train) generated by the radiative cooling of dust aerosols. In the work reported here, we considered the effects of dust aerosols emitted only within the TP itself on regional climate and found that they can also reduce the EASM significantly by weakening the heat source (pump) over the TP and thus reduce the land-sea thermal contrast. The locally generated TP dust can cause surface cooling far downstream in Bohai Gulf and the China-North Korea border area through stationary Rossby wave propagation. Our sensitivity simulations showed there was a negative correlation between the EASM and dust aerosols emitted from the TP locally. 


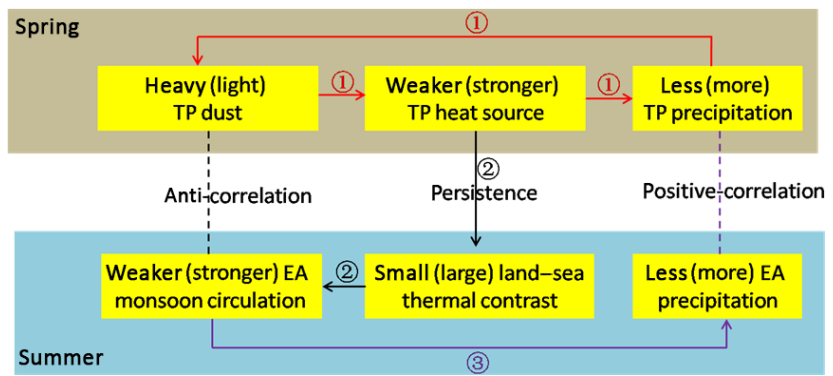

Figure 13. Schematic diagram showing the relationship of dust aerosols emitted from the TP in spring with EASM precipitation. See text for details.

The spring dust aerosols from the TP have a close relationship with EASM. Although the cause-effect relationship is not immediately clear, the following processes are proposed as a possible mechanism based on the results in our simulation (Fig. 13). Firstly, increasing (decreasing) in dust aerosol over the TP in the heavy (light) dust years in spring can weaken (enhance) the TP heat source and thus reduce (increase) precipitation over the TP. Reduction (increase) in precipitation over the TP can also further enhance (diminish) dust emission over the TP (labeled 1 in Fig. 13). Secondly, the weakened (enhanced) TP heat source can persist from spring to summer and shrink (expand) the land-sea thermal contrast and thus weaken (enhance) the EASM. Therefore, the change of dust over the TP is anti-correlated with the variation of EASM circulation intensity (labeled 2). Thirdly, weakened (enhanced) monsoon circulation can reduce (increase) precipitation in East Asia (labeled 3). As a result, the precipitation variation of the TP presents a positive correlation with that of EASM.

It is worth noting that Sun and Liu (2016) demonstrated that dust emitted from Taklimakan and Gobi deserts weakens the Asian monsoon through large-scale atmospheric circulations by $2 \mathrm{~m} \mathrm{~s}^{-1}$ of wind at $700 \mathrm{hPa}$. This magnitude of reduction in the wind seems small compared to the values in the present study even though the emission source extent in the previous study is larger. We think both high-altitude source like the TP and low-altitude sources such as Taklimakan and Gobi deserts can weaken the EASM, but the mechanism could differ. The dust emitted from low-altitude source (mainly Taklimakan and Gobi deserts) reduces the EASM mainly by the large-scale atmospheric disturbances (Rossby wave train), while the dust emitted from high-altitude source weakens the EASM by the reduction in the TP heating and in thermal contrast in the middle troposphere between the land and sea. The column dust load induced by local emissions from the TP in heavy dust years accounted for $20 \%$, (CON-SEN) / CON, of the total loading over the TP; its impacts on Asian monsoon and climate seems more important than the low-altitude sources such as Taklimakan and Gobi deserts in East Asia. This disproportionately large im-

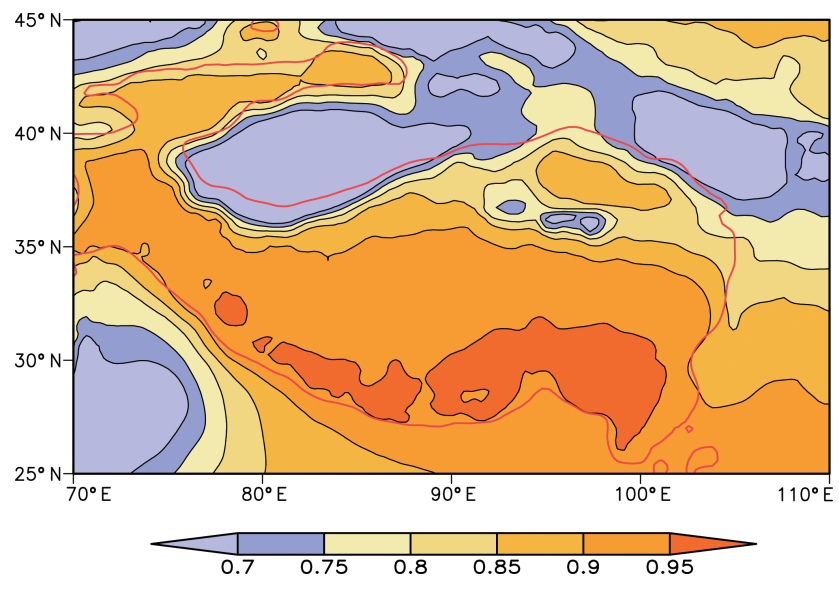

Figure 14. Predicted SSA in summer (CON experiment).

pact from TP locally emitted dust is likely due to its higher elevation within TP itself so that the dust-induced cooling can more effectively weaken the TP from acting as a heat pump for the Asian monsoon. Further studies on this are certainly warranted.

One interesting finding of this study is the net negative radiative heating rate in the lower troposphere over the TP (Fig. 9). Dust direct radiative effects on the atmosphere have been reported to be predominantly positive (warming) over land areas in most previous research (Saeed et al., 2014; Osborne et al., 2011; Zhang et al., 2013; Banks et al., 2014; Chen et al., 2013, 2017). However, the research of Wang et al. (2011) reported strong cooling of dust aerosol in East Asian deserts, and their research demonstrated that dust storms with the same intensity over the East Asia deserts and nearby regions may have different or even opposite direct radiative effects on the Earth-atmosphere system, including its thermodynamic and dynamic structures, depending on season and time (of day) of dust storm occurrence. Here we offer following possible explanations for the lower tropospheric cooling:

1. Magnitudes and even signs of dust aerosol direct radiative forcing in solar spectrum on the atmosphere are largely determined by the aerosol single-scattering albedo (SSA) and to a lesser degree by the albedo of the underlying surface. The SSA of dust aerosols is determined by size distribution, morphology and complex refractive index (Moosmüller et al., 2009). The chemical composition of dust also effects SSA values. For example, the SSA of fine mineral dust particles is determined by iron concentration (Moosmüller et al., 2012). Depending on their sources, the SSA of the dust aerosols can be quite different. Figure 14 shows the spatial distribution of SSA as calculated in the RegCM4.1. The SSA values are $>0.9$ over the TP, considerably larger than those over Taklimakan, Gobi and Great Indian deserts, where SSA is about 0.7. Past studies have shown that the 
radiative roles of dust aerosol plays is largely dependent on SSA. A $5 \%$ change in its value can significantly alter the magnitudes or even sign of SW radiative forcing (Hatzianastassiou et al., 2004; Solmon et al., 2008; Das et al., 2015b; Papadimas et al., 2012). Over the TP with SSA $>0.9$, only less than $10 \%$ of extinct solar radiation is absorbed by the dust aerosol, compared to $20-30 \%$ elsewhere, meaning that the TP dust aerosol is only onethird to one-half the efficiency of those over surrounding sources.

Why is SSA of the TP dust aerosol smaller than dust elsewhere? For a given wavelength, SSA depends on dust particle size, among other factors. The dust particle size spectrum varies among different sources. Those fine dust particles $(0.01-1.0 \mu \mathrm{m})$ over the large part of TP contribute as much as $70 \%$ of total dust particles mass compared to $50-60 \%$ in Taklimakan Desert and some other areas (figure not shown).

2. Unlike SW forcing that occurs only in the daylight hours, the LW cooling persists day and night. In addition, the TP dust tends to exist during night because of the nocturnal convergence driven by diurnal cycle of thermodynamics over the TP (Liu et al., 2009). This would further minimize the already weakened SW absorption (Fig. S1). The combination of reduced SW heating and maintaining of LW cooling resulted in a net negative radiative heating rate in the lowest 200$300 \mathrm{hPa}$ of troposphere shown in Fig. 9.

3. Because of the off-noon emission of dust in the TP, the zenith angle would be larger than near noontime. The investigation of Quijano et al. (2000) showed that dust direct radiative effects can become negative under specific situations like a large zenith angle. In fact many previous studies showed local noon instantaneous irradiance when zenith angle is smaller. This potentially relatively larger zenith angle may also contribute to the net negative radiative heating rate. In addition, many dust studies are during dust storm events, most notably in daytime at the synoptic scale ( $\sim$ days), while our study is at the climate scale ( $\sim$ years). The feedback processes are more complex as the timescale grows larger. For example, the heating rate in Fig. $9 \mathrm{c}$ and $\mathrm{d}$ that looks more extensive than the net radiative flux reflects the contribution to the cooling from other processes.

Although Fig. 9 shows a negative heating rate over the TP within the lowest $200-300 \mathrm{hPa}$ of the atmosphere locally, the absorbed SW by atmospheric column measured by the flux difference between the top of the atmosphere (TOA) and surface, as normally done in the literature, is still positive outside TP over major source regions (Fig. S2b minus Fig. S2a). Thus strictly speaking, by conventional definitions, the absorbed SW radiation is still mostly positive over the whole domain, even though the TP dust results in a cooling effect in the lower troposphere locally (Fig. S2e, f).
Finally it is noteworthy that, given the large variability of dust SSA among different sources in Asia, it is possible that the magnitudes or even signs of dust direct net radiative forcing on the atmosphere could vary among case studies and climate simulations over different continents. For example, the LW forcing of dust at Zhangye, China, was found to be about a factor of 2 larger than that over Saharan measured at Sal Island, Cabo Verde, owing to differences in the dust absorptive properties (Hansell et al., 2012).

It is very beneficial to study the impact of aerosols on climate using a regional climate model (RCM) instead of a coarse-resolution global climate model (GCM). However, limited-area RCMs naturally cannot fully account for external forcing remote from the domain of interest although the lateral boundary conditions allow large-scale features to propagate into the domain. Our domain size $(9600 \times 640 \mathrm{~km})$ is reasonably large enough so that the weather and climate systems can have adequate spatial extent to develop within the domain, as attested by reasonable validation of wind pattern, temperature field and precipitation (Sect. 3.1). Caution should be exercised, however, as results from regional simulations could be somewhat domain-size dependent quantitatively although main results should not be affected. It is worth mentioning that the model's internal variability could influence the results; thus, we compared the standard deviation of summer surface temperature and precipitation in $\mathrm{CON}$ with the signal induced by the dust effects (CON minus SEN) during the heavy dust years. The signal induced by the dust is much greater than the standard deviations (figures not shown). Therefore, the dust effect reported in our simulation is significant in the heavy dust years.

Only direct radiative effects of dust were included in our model and future studies should include both direct and indirect effects. The semi-direct effects (Hansen et al., 1997) are included in this study as part of atmospheric feedback, but are not explicitly discussed here since they would be better discussed along with the indirect effects as both involve clouds. The simulated effects of dust aerosols on climate were highly sensitive to the physical characteristics of the dust aerosols, such as the SSA (Huang et al., 2014; Colarco et al., 2014; Das et al., 2015b). Therefore our results also need to be validated by sensitivity experiments using aerosols with different properties. A recent study by Tsikerdekis et al. (2017) demonstrated that simulated dust load and induced radiation change are sensitive to the dust particle size division in the model, so further sensitivity experiments using more dust size bins would be worthwhile. In addition, many other factors can also affect the EASM, including the El Niño-Southern Oscillation (Zhao et al., 2012; Liu et al., 2015), the North Atlantic Oscillation (Wu et al., 2009) and heat sources over the TP (Yanai et al., 2006; Duan et al., 2012). A recent numerical simulation by Wang et al. (2017) showed that aerosol emissions from outside East Asian play an important part in weakening the circulation of the EASM. 


\section{Conclusions}

We conducted two numerical experiments to quantify the effects of dust aerosols emitted over the TP on the EASM in heavy/light dust years using a high-resolution RCM. Satellite and in situ observations were used to evaluate the simulated spatial distribution of dust aerosols and their seasonal and interannual variations. We analyzed the change in dust aerosols induced by emissions over the TP and their radiative effects on the EASM and summer precipitation in heavy/light dust years.

The spatiotemporal distribution of the dust AOD and their seasonal and interannual variation were captured well by the RegCM4.1 model compared with the MISR AOD and in situ observations from AERONET. Both the simulated and observed AOD were higher in spring/summer and lower in autumn/winter. The simulated dust AOD was higher in the Taklimakan, Gobi and Great Indian deserts, with peak values of $>0.6$. The simulated dust AOD in the Qaidam Basin and the northern TP was also higher. The seasonal variation in the dust AOD at Nam Co was captured well by RegCM4.1 compared to the observed aerosol AOD.

Comparative analyses of the two simulations indicated that the dust aerosols generated over the TP had a profound influence on the EASM. The differences in the EASM index and column dust load between CON and SEN experiments are negatively correlated $(r=-0.46)$. The index also weakened (strengthened) as the combined imported-local dust aerosol increased (decreased) over the TP. The net atmospheric heating rate was negative over the TP in heavy dust years as a result of the radiative cooling effects of the dust aerosols, leading to a $0.6^{\circ} \mathrm{C}$ cooling in the surface and atmospheric temperatures. The land-sea thermal contrast and EASM were therefore both weakened, causing a $27 \%$ reduction in precipitation in the southern monsoon region. The dust load over the TP in the light dust years was much less than in the heavy dust years, implying large interannual variability.

Data availability. Model outputs are stored in the Galactic GT8000 super-blade computing system at the Institute of Earth Environment, Chinese Academy of Sciences, and they are available upon request from Hui Sun (sunhui@ieecas.cn). The public data, including CRU, NCEP-DOE, MISR, CALIPSO and AERONET data used in this study, can be obtained from https://crudata. uea.ac.uk/cru/data/hrg/cru_ts_3.23/cruts.1506241137.v3.23/, https://www.esrl.noaa.gov/, http://www-misr.jpl.nasa.gov/, https://eosweb.larc.nasa.gov/ and https://aeronet.gsfc.nasa.gov/, respectively.

Competing interests. The authors declare that they have no conflict of interest.

\section{The Supplement related to this article is available online at https://doi.org/10.5194/acp-17-13731-2017- supplement.}

Acknowledgements. The authors thank the two anonymous reviewers for valuable comments and suggestions. This research was jointly supported by the National Key Research and Development Program of China (2016YFA0601904) and the National Natural Science Foundation of China (41405093, 41572150 and 41475085).

Edited by: Nikos Hatzianastassiou

Reviewed by: two anonymous referees

\section{References}

Alfaro, S. C. and Gomes, L.: Modeling mineral aerosol production by wind erosion: emission intensities and aerosol size distributions in source areas, J. Geophys. Res., 106, 18075-18084, https://doi.org/10.1029/2000JD900339, 2001.

Amiridis, V., Wandinger, U., Marinou, E., Giannakaki, E., Tsekeri, A., Basart, S., Kazadzis, S., Gkikas, A., Taylor, M., Baldasano, J., and Ansmann, A.: Optimizing CALIPSO Saharan dust retrievals, Atmos. Chem. Phys., 13, 1208-12106, https://doi.org/10.5194/acp-13-12089-2013, 2013.

Anthes, R. A.: A cumulus parameterization scheme utilizing a one-dimensional cloud model, Mon. Weather Rev., 105, 270-286, https://doi.org/10.1175/15200493(1977)105<0270:ACPSUA>2.0.CO;2, 1977.

Banks, F. R., Brindley, H. E., Hobby, M., and Marsham, F. H.: The daytime cycle in dust aerosol direct radiative effects observed in the central Sahara during the Fennec campaign in June 2011, J. Geophys. Res., 119, 13861-13876, https://doi.org/10.1002/2014JD022077, 2014.

Bibi, H., Alam, K., Chishtie, F., Bibi, S., Shahid, I., and Blaschke, T.: Intercomparison of MODIS, MISR, OMI, and CALIPSO aerosol optical depth retrievals for four locations on the IndoGangetic plains and validation against AERONET data, Atmos. Environ., 111, 113-126, 2015.

Chen, S. Y., Huang, J. P., Zhao, C., Qian, Y., Leung, R., and Yang, B.: Modeling the transport and radiative forcing of Taklimakan dust over the Tibetan Plateau: A case study in the summer of 2006, J. Geophys. Res., 118, 797-812, https://doi.org/10.1002/jgrd.50122, 2013.

Chen, S., Huang, J., Kang, L., Wang, H., Ma, X., He, Y., Yuan, T., Yang, B., Huang, Z., and Zhang, G.: Emission, transport, and radiative effects of mineral dust from the Taklimakan and Gobi deserts: comparison of measurements and model results, Atmos. Chem. Phys., 17, 2401-2421, https://doi.org/10.5194/acp17-2401-2017, 2017.

Colarco, P. R., Nowottnick, E. P., Randles, C. A., Yi, B. Q., Yang, P., Kim, K. M., Smith, J. A., and Bardeen, C. G.: Impact of radiatively interactive dust aerosols in the NASA GEOS-5 climate model: sensitivity to dust particle shape and refractive index, J. Geophys. Res., 119, 753-786, https://doi.org/10.1002/2013JD020046, 2014.

Das, S., Dey, S., and Dash, S. K.: Impacts of aerosols on dynamics of Indian summer monsoon using a regional climate model, 
Clim. Dynam., 44, 1685-1697, https://doi.org/10.1007/s00382014-2284-4, 2015a.

Das, S., Dey, S., Dash, S. K., Giuliani, G., and Solmon, F.: Dust aerosol feedback on the Indian summer monsoon: sensitivity to absorption property, J. Geophys. Res., 120, 9642-9652, https://doi.org/10.1002/2015JD023589, 2015b.

Das, S., Dey, S., and Dash, S. K.: Direct radiative effects of anthropogenic aerosols on Indian summer monsoon circulation, Theor. Appl. Climatol., 124, 629-639, https://doi.org/10.1007/s00704015-1444-8, 2016.

Dickinson, R. E., Henderson-Sellers, A., and Kennedy, P. J.: Biosphere-atmosphere transfer scheme (bats) version 1e as coupled to the NCAR community climate model, NCAR Tech., National Center for Atmospheric Research Technical Note No. TN387+STR, NCAR, Boulder, CO, 1993.

Duan, A., Wu, G., Liu, Y., Ma, Y., and Zhao, P.: Weather and climate effects of the Tibetan Plateau, Adv. Atmos. Sci., 29, 978-992, https://doi.org/10.1007/s00376-012-1220-y, 2012.

Emanuel, K. A.: A scheme for representing cumulus convection in large-scale models, J. Atmos. Sci., 48, 2313-2335, https://doi.org/10.1175/15200469(1991)048<2313:ASFRCC>2.0.CO;2, 1991.

Fang, X. M.: The origin and provenance of the Malan loess along the eastern margin of the Qinhai-Xizang (Tibetan) Plateau and its adjacent area, Sci. China SER B, 38, 876-887, 1995.

Fang, X. M., Li, J. J., and Van der Voo, R.: Rock magnetic and grain size evidence for intensified Asian atmospheric circulation since 800,000 years BP related to Tibetan uplift, Earth Planet. Sci. Lett., 165, 129-144, https://doi.org/10.1016/S0012821X(98)00259-3, 1999.

Fécan, F., Marticorena, B., and Bergametti, G.: Parametrization of the increase of the aeolian erosion threshold wind friction velocity due to soil moisture for arid and semi-arid areas, Ann. Geophys., 17, 149-157, https://doi.org/10.1007/s00585-999-0149-7, 1999.

Gao, X. J., Xu, Y., Zhao, Z. C, Pal, J. S., and Giorgi, F.: On the role of resolution and topography in the simulation of East Asia precipitation, Theor. Appl. Climatol., 86, 173-185, https://doi.org/10.1007/s00704-005-0214-4, 2006.

Goudie, A. S.: Dust storms in space and time, Prog. Phys. Geog., 7, 502-530, https://doi.org/10.1177/030913338300700402, 1983.

Grell, G. A., Dudhia, J., and Stauffer, D. R.: Description of the fifth generation Penn State/NCAR Mesoscale Model (MM5), National Center for Atmospheric Research Technical Note No. TN-398+STR, NCAR, Boulder, CO, 1994.

Grell, G. A.: Prognostic evaluation of assumptions used by cumulus parameterizations, Mon. Weather Rev., 121, 764-787, https://doi.org/10.1175/15200493(1993)121<0764:PEOAUB>2.0.CO;2, 1993.

Guo, J. and Yin, Y.: Mineral dust impacts on regional precipitation and summer circulation in East Asia using a regional coupled climate system model, J. Geophys. Res., 120, 10378-10398, https://doi.org/10.1002/2015JD023096, 2015.

Hansell, R. A., Tsay, S., Hsu, N. C., Ji, Q., Bell, S. W., Brent, N. H., Welton, E. J., Roush, T. L., Zhang, W., Huang, J., Li Z. Q., and Chen, H.: An assessment of the surface longwave direct radiative effect of airborne dust in Zhangye, China, during the Asian Monsoon Years field experiment (2008), J. Geophys. Res., 117, D00K39, https://doi.org/10.1029/2011JD017370, 2012.
Hansen, J. E., Sato, M., and Ruedy, R.: Radiative forcing and climate response, J. Geophys. Res., 102, 6831-6864, 1997.

Hatzianastassiou, N., Katsoulis, B., and Vardavas, I.: Sensitivity analysis of aerosol direct radiative forcing in ultraviolet-visible wavelengths and consequences for the heat budget, Tellus B, 56, 368-381, https://doi.org/10.3402/tellusb.v56i4.16439, 2004.

Hess, H., Kophke, P., and Schult, I.: Optical properties of aerosols and clouds: The software package OPAC, B. Am. Meteorol. Soc., 79, 831-844, https://doi.org/10.1175/15200477(1998)079<0831:OPOAAC >2.0.CO;2, 1998.

Holtslag, A., De Bruijn, E., and Pan, H. L.: A high resolution air mass transformation model for short-range weather forecasting, Mon. Weather Rev., 118, 1561-1575, https://doi.org/10.1175/15200493(1990)118<1561:AHRAMT>2.0.CO;2, 1990.

Huang, J. P., Minnis, P., Yi, Y. H., Tang, Q., Wang, X., Hu, Y. X., Liu, Z. Y., Ayers, K., Trepte, C., and Winker, D.: Summer dust aerosols detected from CALIPSO over the Tibetan Plateau, Geophys. Res. Lett., 34, L18805, https://doi.org/10.1029/2007GL029938, 2007.

Huang, J., Fu, Q., Su, J., Tang, Q., Minnis, P., Hu, Y., Yi, Y., and Zhao, Q.: Taklimakan dust aerosol radiative heating derived from CALIPSO observations using the Fu-Liou radiation model with CERES constraints, Atmos. Chem. Phys., 9, 4011-4021, https://doi.org/10.5194/acp-9-4011-2009, 2009.

Huang, J. P., Wang, T., Wang, W., Li, Z., and Yan, H.: Climate effects of dust aerosols over East Asian arid and semi-arid regions, J. Geophys. Res., 110, 11398-11416, https://doi.org/10.1002/2014JD021796, 2014.

Ji, Z. M., Kang, S. C., Zhang, D. F., Zhu, C. Z., Wu, J., and Xu, Y.: Simulation of the anthropogenic aerosols over South Asia and their effects on Indian summer monsoon, Clim. Dynam., 36, 1633-1647, https://doi.org/10.1007/s00382-010-0982-0, 2011.

Ji, Z. M., Kang, S. C., Cong, Z. Y., Zhang, Q. G., and Yao, T. D.: Simulation of carbonaceous aerosols over the Third Pole and adjacent regions: distribution, transportation, deposition, and climatic effects, Clim. Dynam., 45, 2831-2846, https://doi.org/10.1007/s00382-015-2509-1, 2015.

Jia, R., Liu, Y., Chen, B., Zhang, Z., and Huang, J.: Source and transportation of summer dust over the Tibetan Plateau, Atmos. Environ., 123, 210-219, https://doi.org/10.1016/j.atmosenv.2015.10.038, 2015.

Jiang, D. B. and Lang, X. M.: Last Glacial Maximum East Asian monsoon: results of PMIP simulations, J. Clim., 23, 5030-5038, https://doi.org/10.1175/2010JCLI3526.1, 2010.

Kalnay, E., Kanamitsu, M., Kistler, R., Collins, W. G., Deaver, D., Gandin, L. S., Iredell, M., Saha, S., White, G., Woollen, J., Zhu, Y., Chelliah, M., Ebisuzaki, W., Higgins, W., Janowiak, J. E., Mo, K., Ropelewski, C., Wang, J. L., and Leetmaa, A.: The NCEP/NCAR 40-year reanalysis project, Bull. Am. Meteorol. Soc., 77, 437-471, https://doi.org/10.1175/15200477(1996)077<0437:TNYRP>2.0.CO;2, 1996.

Kiehl, J., Hack, J., Bonan, G., Boville, B., Breigleb, B., Williamson, D., and Rasch, P.: Description of the NCAR community climate model (CCM3), National Center for Atmospheric Research Technical Note No. NACR/TN-420+STR, NCAR, Boulder, CO, 1996.

Lau, K. M., Kim, M. K, and Kim, K. M.: Asian monsoon anomalies induced by aerosol direct forcing: the role of the Tibetan Plateau, 
Clim. Dynam., 26, 855-64, https://doi.org/10.1007/s00382-0060114-z, 2006.

Lau, K. M., Kim, M. K., Kim, K. M., and Lee, W. S.: Enhanced surface warming and accelerated snow melt in the Himalayas and Tibetan Plateau induced by absorbing aerosols, Environ. Res. Lett., 5, 025204, https://doi.org/10.1088/1748-9326/5/2/025204, 2010.

Li, S., Wang, T. J, Solmon, F., Zhuang, B. L., Wu, H., Xie, M., Han, Y., and Wang, X. M.: Impact of aerosols on regional climate in southern and northern China during strong/weak East Asian summer monsoon years, J. Geophys. Res., 121, 40694081, https://doi.org/10.1002/2015JD023892, 2016.

Liu, D., Wang, Z., Liu, Z., Winker, D., and Trepte, C.: A height resolved global view of dust aerosols from the first year CALIPSO lidar measurements, J. Geophys. Res., 113, D16214, https://doi.org/10.1029/2007JD009776, 2008.

Liu, X. D., Bai, A. J., and Liu, C. H.: Diurnal variations of summertime precipitation over the Tibetan Plateau in relation to orographically-induced regional circulations, Environ. Res. Lett., 4, 045203, https://doi.org/10.1088/1748-9326/4/4/045203, 2009.

Liu, Y. Y., Hu, Z. Z., Kumar, A., Peng, P., Collins, D. C., and Jha, B.: Tropospheric biennial oscillation of summer monsoon rainfall over East Asia and its association with ENSO, Clim. Dynam., 45, 1747-1759, https://doi.org/10.1007/s00382-014-2429$5,2015$.

Lou, S., Russell, L. M., Yang, Y., Xu, L., Lamjiri, M. A., DeFlorio, M. J., Miller, A. J., Ghan, S. J., Liu, Y., and Singh, B.: Impacts of the East Asian Monsoon on springtime dust concentrations over China, J. Geophys. Res., 121, 8137-8152, https://doi.org/10.1002/2016JD024758, 2016.

Loveland, T. R., Reed, B. C., Brown, J. F., Ohlen, D. O., Zhu, Z., Yang, L., and Merchant, J. W.: Development of a global land cover characteristic database and IGBP DISCover from 1-km AVHRR data, Int. J. Remote Sens., 21, 1303-1330, https://doi.org/10.1080/014311600210191, 2000.

Marinou, E., Amiridis, V., Binietoglou, I., Tsikerdekis, A., Solomos, S., Proestakis, E., Konsta, D., Papagiannopoulos, N., Tsekeri, A., Vlastou, G., Zanis, P., Balis, D., Wandinger, U., and Ansmann, A.: Three-dimensional evolution of Saharan dust transport towards Europe based on a 9-year EARLINEToptimized CALIPSO dataset, Atmos. Chem. Phys., 17, 58935919, https://doi.org/10.5194/acp-17-5893-2017, 2017.

Marticorena, B. and Bergametti, G.: Modeling the atmospheric dust cycle: 1. Design of a soil-derived dust emission scheme, J. Geophys. Res., 100, 16415-16430, https://doi.org/10.1029/95JD00690, 1995.

Martonchik, J. V., Diner, D. J., Kahn, R. A., Ackerman, T. P., Verstraete, M. E., Pinty, B., and Gordon, H. R.: Techniques for the retrieval of aerosol properties over land and ocean using multiangle imaging, IEEE T. Geosci. Remote Sens., 36, 1212-1227, 1998.

Martonchik, J. V., Diner, D. J., Kahn, R., Gaitley, B., and Holben, B. N.: Comparison of MISR and AERONET aerosol optical depths over desert sites, Geophys. Res. Lett., 31, L16102, https://doi.org/10.1029/2004GL019807, 2004.

Mbienda, A. J. K., Tchawoua, C., Vondou, D. A., Choumbou, P., Sadem, C. K., and Dey, S.: Impact of anthropogenic aerosols on climate variability over Central Africa by us- ing a regional climate model, Int. J. Climatol., 37, 249-267, https://doi.org/10.1002/joc.4701, 2017.

Miller, R. L., Perlwitz, J., and Tegen, I.: Modeling Arabian dust mobilization during the Asian summer monsoon: The effect of prescribed versus calculated SST, Geophys. Res. Lett., 31, 519540, https://doi.org/10.1029/2004GL020669, 2004.

Mitchell, T. D. and Jones, P. D.: An improved method of constructing a database of monthly climate observations and associated high-resolution grids, Int. J. Climatol., 25, 693-712, https://doi.org/10.1002/joc.1181, 2005.

Moosmüller, H. and Arnott, W. P.: Particle optics in the Rayleigh regime, J. Air Waste Manage. Assoc., 59, 1028-1031, https://doi.org/10.3155/1047-3289.59.9.1028, 2009.

Moosmüller, H., Engelbrecht, J. P., Skiba, M., Frey, G., Chakrabarty, R. K., and Arnott, W. P.: Single scattering albedo of fine mineral dust aerosols controlled by iron concentration, J. Geophys. Res., 117, D11210, https://doi.org/10.1029/2011JD016909, 2012.

Oleson, K. W., Niu, G. Y., Yang, Z. L., Lawrence, D. M., Thornton, P. E., Lawrence, P. J., Stockli, R., Dickinson, R. E., Bonan, G. B., Levis, S., Dai, A., and Qian, T.: Improvements of the Community Land Model and their impact on the Hydrological cycle, J. Geophys. Res., 113, 811-827, https://doi.org/10.1029/2007JG000563, 2008.

Osborne, S. R., Baran, A. J., Johnson, B. T., Haywood, J. M., Hesse, E., and Newman, S.: Short-wave and long-wave radiative properties of Saharan dust aerosol, Q. J. Roy. Meteor. Soc., 137, 11491167, https://doi.org/10.1002/qj.771, 2011.

Papadimas, C. D., Hatzianastassiou, N., Matsoukas, C., Kanakidou, M., Mihalopoulos, N., and Vardavas, I.: The direct effect of aerosols on solar radiation over the broader Mediterranean basin, Atmos. Chem. Phys., 12, 7165-7185, https://doi.org/10.5194/acp-12-7165-2012, 2012.

Park, S. S. and Kim, Y. J.: Source contributions to fine particulate matter in an urban atmosphere, Chemosphere, 59, 217-226, https://doi.org/10.1016/j.chemosphere.2004.11.001, 2005.

Qian, Y. and Giorgi, F.: Interactive coupling of regional climate and sulfate aerosol models over East Asia, J. Geophys. Res., 104, 6477-6499, https://doi.org/10.1029/98JD02347, 1999.

Qian, Y., Giorgi, F., Huang, Y., Chameides, W., and Luo, C.: Regional simulation of anthropogenic sulfur over East Asia and its sensitivity to model parameters, Tellus B, 53, 171-191, https://doi.org/10.1034/j.1600-0889.2001.d01-14.x, 2001.

Qian, Y., Leung, L. R., Ghan, S. J., and Giorgi, F.: Regional climate effects of aerosols over China: Modeling and observation, Tellus B, 55, 914-934, https://doi.org/10.1046/j.14356935.2003.00070.x, 2003.

Quijano, A. L., Sokolik, I. N., and Toon, B.: Radiative heating rates and direct radiative forcing by mineral dust in cloudy atmospheric conditions, J. Geophys. Res., 105, 12207-12219, https://doi.org/10.1029/2000JD900047, 2000.

Reynolds, R. W., Rayner, N. A., Smith, T. M., Stokes, D. C., and Wang, W. Q.: An improved in situ and satellite SST analysis for climate, J. Clim., 15, 1609-1625, https://doi.org/10.1175/15200442(2002)015<1609:AIISAS>2.0.CO;2, 2002.

Rosenfeld, D., Rudich, Y., and Lahav, R.: Desert dust suppressing precipitation: A possible desertification loop, P. Natl. Acad. Sci. USA, 98, 5975-5980, https://doi.org/10.1073/pnas.101122798, 2001. 
Saeed, T. M., Al-Dashti, H., and Spyrou, C.: Aerosol's optical and physical characteristics and direct radiative forcing during a shamal dust storm, a case study, Atmos. Chem. Phys., 14, 37513769, https://doi.org/10.5194/acp-14-3751-2014, 2014.

Solmon, F., Mallet, M., Elguindi, N., Giorgi, F., Zakey, A., and Konaré, A.: Dust aerosol impact on regional precipitation over western Africa, mechanisms and sensitivity to absorption properties, Geophys. Res. Lett., 35, L24705, https://doi.org/10.1029/2008GL035900, 2008.

Sun, H. and Liu, X. D.: Numerical modeling of topographymodulated dust aerosol distribution and its influence on the onset of East Asian summer monsoon, Adv. Meteorol., 2016, 1-15, https://doi.org/10.1155/2016/6951942, 2016.

Sun, H., Pan, Z. T., and Liu, X. D.: Numerical simulation of spatialtemporal distribution of dust aerosol and its direct radiative effects on East Asian climate, J. Geophys. Res., 117, 110-117, https://doi.org/10.1029/2011JD017219, 2012.

Tegen, I. and Lacis, A. A.: Modeling of particle size distribution and its influence on the radiative properties of mineral dust aerosol, J. Geophys. Res., 101, 19237-19244, https://doi.org/10.1029/95JD03610, 1996.

Tsikerdekis, A., Zanis, P., Steiner, A. L., Solmon, F., Amiridis, V., Marinou, E., Katragkou, E., Karacostas, T., and Foret, G.: Impact of dust size parameterizations on aerosol burden and radiative forcing in RegCM4, Atmos. Chem. Phys., 17, 769-791, https://doi.org/10.5194/acp-17-769-2017, 2017.

Uno, I., Eguchi, K., Yumimoto, K., Takemura, T., Shimizu, A., Uematsu, M., Liu, Z., Wang, Z., Hara, Y., and Sugimoto, N.: Asian dust transported one full circuit around the globe, Nat. Geosci., 2, 557-560, https://doi.org/10.1038/ngeo583, 2009.

Wang, B., Wu, Z., Li, J., Liu, J., Chang, C. P., Ding, Y., and Wu, G.: How to measure the strength of the East Asian summer monsoon, J. Clim., 21, 4449-4463, https://doi.org/10.1175/2008JCLI2183.1, 2008.

Wang, C. T. and Yu, L.: Sensitivity of regional climate model to different cumulus parameterization schemes in simulation of the Tibetan Plateau climate, Chin. J. Atmos. Sci., 35, 1132-1144, 2011 (in Chinese).

Wang, H., Shi, G. Y., Li, S. Y., Li, W., Wang, B., and Huang, Y. B.: The impacts of optical properties on radiative forcing due to dust aerosol, Adv. Atmos. Sci., 23, 431-441, https://doi.org/10.1007/s00376-006-0431-5, 2006.

Wang, H., Zhao, T. L., Zhang, X. Y., and Gong, S. L.: Dust direct radiative effects on the earth-atmosphere system over East Asia: early spring cooling and late spring warming, Chinese Sci. Bull., 56, 1020-1030, https://doi.org/10.1007/s11434-011-44053, 2011 .

Wang, Q. Y., Zhang, Z. L., and Zhang, H.: Impact of anthropogenic aerosols from global, East Asian, and non-East Asian sources on East Asian summer monsoon system, Atmos. Res., 183, 224 236, https://doi.org/10.1016/j.atmosres.2016.08.023, 2017.

Wang, Y. Q., Zhang, X. Y., Gong, S. L., Zhou, C. H., Hu, X. Q., Liu, H. L., Niu, T., and Yang, Y. Q.: Surface observation of sand and dust storm in East Asia and its application in CUACE/Dust, Atmos. Chem. Phys., 8, 545-553, https://doi.org/10.5194/acp-8545-2008, 2008.

Winker, D. M., Tackett, J. L., Getzewich, B. J., Liu, Z., Vaughan, M. A., and Rogers, R. R.: The global 3-D distribution of tropospheric aerosols as characterized by CALIOP, Atmos.
Chem. Phys., 13, 3345-3361, https://doi.org/10.5194/acp-133345-2013, 2013.

Wu, G., Liu, Y., He, B., Bao, Q., Duan, A., and Jin, F. F.: Thermal controls on the Asian summer monsoon, Sci. Rep.-UK, 2, 404, https://doi.org/10.1038/srep00404, 2012.

Wu, Z., Wang, B., Li, J., and Jin, F. F.: An empirical seasonal predication model of the east Asian summer monsoon using ENSO and NAO, J. Geophys. Res., 114, 85-86, https://doi.org/10.1029/2009JD011733, 2009.

Xie, X., Wang, H., Liu, X., Li, J., Wang, Z., and Liu, Y.: Distinct effects of anthropogenic aerosols on the effect Asian summer monsoon between multidecadal strong and weak monsoon stages, J. Geophys. Res., 121, 7026-7040, https://doi.org/10.1002/2015JD024228, 2016.

Yanai, M., Wu, G. X., and Wang, B.: Effects of the Tibetan Plateau in the Asian Monsoon, Springer, Berlin, 513-549, 2006.

Zakey, A. S., Solmon, F., and Giorgi, F.: Implementation and testing of a desert dust module in a regional climate model, Atmos. Chem. Phys., 6, 4687-4704, https://doi.org/10.5194/acp-6-46872006, 2006.

Zanis, P.: A study on the direct effect of anthropogenic aerosols on near surface air temperature over Southeastern Europe during summer 2000 based on regional climate modeling, Ann. Geophys., 27, 3977-3988, https://doi.org/10.5194/angeo-27-39772009, 2009.

Zanis, P., Ntogras, C., Zakey, A., Pytharoulis, I., and Karacostas, T.: Regional climate feedback of anthropogenic aerosols over Europe using RegCM3, Clim. Res., 52, 267-278, https://doi.org/10.3354/cr01070, 2012.

Zhang, X. Y., Zhang, G. Y., Zhu, G. H., Zhang, D. R., An, Z. S., Chen, T., and Huang, X. P.: Elemental tracers for Chinese source dust, Sci. China Ser. D, 39, 512-521, 1996.

Zhang, D. F., Gao, X. J., Ouyang, L. C., and Dong, W. J.: Simulation of present climate over East Asia by a regional climate model, J. Trop. Meteorol., 14, 19-23, 2008.

Zhang, D. F., Zakey, A. S., Gao, X. J., Giorgi, F., and Solmon, F.: Simulation of dust aerosol and its regional feedbacks over East Asia using a regional climate model, Atmos. Chem. Phys., 9, 1095-1110, https://doi.org/10.5194/acp-9-1095-2009, 2009.

Zhang, L., Li, Q. B., Gu, Y., Liou, K. N., and Meland, B.: Dust vertical profile impact on global radiative forcing estimation using a coupled chemical-transport-radiative-transfer model, Atmos. Chem. Phys., 13, 7097-7114, https://doi.org/10.5194/acp13-7097-2013, 2013.

Zhao, T. L., Gong, S. L., Zhang, X. Y., Blanchet, J. P., Mckendry, I. G., and Zhou, Z. J.: A simulated climatology of Asian dust aerosol and its trans-pacific transport Part I: mean climate and validation, J. Clim., 19, 104-122, https://doi.org/10.1175/JCLI3606.1, 2006

Zhao, T. L., Gong, S. L., Huang, P., and Lavoué, D.: Hemispheric transport and influence of meteorology on global aerosol climatology, Atmos. Chem. Phys., 12, 7609-7624, https://doi.org/10.5194/acp-12-7609-2012, 2012. 